\title{
BIOCIDAL ACTIVITY OF ORIGANUM VULGARE SUBSP. HIRTUM ESSENTIAL OIL
}

\author{
Milena Nikolova ${ }^{1}$, Mariya Yovkova르, Elina Yankova-Tsvetkova ${ }^{1}$, \\ Boryanka Traikova ${ }^{1}$, Tatyana Stefanova ${ }^{1}$, Ina Aneva ${ }^{1}$, Strahil Berkov ${ }^{1}$ \\ ${ }^{1}$ Institute of Biodiversity and Ecosystem Research, Bulgarian Academy of Sciences, 1113 Sofia, Bulgaria \\ Link to this article: https://doi.org/10.11118/actaun.2021.051 \\ Received: 7. 9. 2020, Accepted: 17. 9. 2021
}

To cite this article: NIKOLOVA MILENA, YOVKOVA MARIYA, YANKOVA-TSVETKOVA ELINA, TRAIKOVA BORYANKA, STEFANOVA TATYANA, ANEVA INA, BERKOV STRAHIL. 2021. Biocidal Activity of Origanum vulgare subsp. hirtum Essential Oil. Acta Universitatis Agriculturae et Silviculturae Mendelianae Brunensis, 69(5): 569-578.

\begin{abstract}
Toxic effect of Origanum vulgare subsp. hirtum (Link) Ietsw. essential oil was assayed on weeds (Lolium perenne L. Trifolium pratense L. and Trifolium repens L.), potato plants (Solanum tuberosum L.) and Myzus persicae Sulz. The GC-MS analysis of the essential oil revealed carvacrol as the main component. The essential oil solutions completely inhibited the seed germination of the target weeds at concentration $2 \mu \mathrm{L} / \mathrm{mL}$ in Petri dishes. In contrast, in soil, this effect was achieved at a concentration of $5 \mu \mathrm{L} / \mathrm{mL}$ for studied dicot and at $10 \mu \mathrm{L} / \mathrm{mL}$ for the monocot species. Total destruction of target weeds at post-emergence stage after spraying with solution of the essential oil in concentrate $10 \mu \mathrm{L} / \mathrm{mL}$ was found. Mature potato plants were poorly affected by the essential oil. A completely toxic effect on M. persicae was established by applying a solution with a concentration of $3 \mu \mathrm{L} / \mathrm{mL}$ of the essential oil. The experimental data indicate that the essential oil of the species has great potential, as an alternative to synthetic biocides, for the production of eco-friendly formulations for pest control.
\end{abstract}

Keywords: phytotoxicity, insecticidal, carvacrol, Greek oregano, Myzus persicae, weeds

\section{INTRODUCTION}

The extensive use of synthetic biocides in the modern agriculture results in grave environmental and health problems. The negative consequences of their use provoke intensive research of natural products as an alternative for pest control. Natural biocides have advantages over the synthetic, such as rapid biodegradation, low toxicity to non-target organisms, and unique modes of action with little mammalian toxicity (Mann and Kaufman, 2012).

Plants are an important source of bioactive compounds. They produce secondary metabolites as defence compounds against abiotic (ca. UV radiation) and biotic ( $\mathrm{ca}$. herbivores and microorganisms) factors or allelochemicals that provide them advantages in the competition for resources within the plant communities (Berkov et al., 2014). The knowledge about the chemoeclogical interactions of the plants with other organisms is a starting point for the discovery of new natural biocide molecules with a potential for application in agriculture. Many compounds belonging to the major groups of natural compounds, such as alkaloids, terpenes, sterols, flavones, coumarins, iridoids, phenylpropanoids, have been active against different organisms, including pests (González-Coloma et al., 2013). The monoterpenes are the wealthiest group of compounds with biocidal activities (Vokou et al., 2003; Dayan et al., 2009).

Hydrocarbon and oxygenated monoterpenes and sesquiterpenes are the main components in the essential oils, which also may contain phenylpropanoids, hydrocarbons and compounds from other chemical classes. Particularly abundant in the aromatic plants, the essential oils have been intensively studied for their herbicidal and insecticidal potential during the last decades (De Almeida et al., 2010; Amri et al., 2013a; Ibañez 
et al., 2017; Synowiec et al., 2017). The screening for herbicidal activity initially includes assessment of the effects of the tested compound(s), extract(s) or product(s) on seed germination and seedling growth (Scognamiglio et al., 2013; Amri et al., 2013; Dayan et al., 2009; Dhifi et al., 2016).

Origanum vulgare L., also known as oregano, is an important medicinal and aromatic plant with application in culinary and folk medicine. Recent studies on allelopathic effects of $O$. vulgare essential oils and extracts on other plants, insects and microorganisms indicate interesting biocidal activities (Dragoeva et al., 2014; García-Beltrán and Esteban, 2016). Green manure and water extracts from $O$. vulgare have shown phytotoxic effects on barnyard grass (Echinochloa crus-galli), bristly foxtail (Setaria verticillata), common purslane (Portulaca oleracea), cotton (Gossypium hirsutum), and corn (Zea mays) (Vasilakoglou et al., 2011). Thymol type essential oil from $O$. vulgare has shown significant phytotoxic effects on the monocot Triticum aestivum and Hordeum vulgare as well as on dicot Lepidium sativum and Sinapis alba. However, it does not influence these species' germination (Grul'ová et al., 2020). Carvacrol type oregano essential oils inhibited seed germination and seedling growth of Portulaca oleracea L., Lolium multiflorum Lam. and Echinochloa crus-galli (L.) Beauv., at all concentrations assayed (0.125-1 $\mu \mathrm{L} / \mathrm{mL}$ ) (Ibáñez and Blázquez, 2017).

Origanum vulgare is represented by six subspecies worldwide O. vulgare subsp. glandulosum (Desf.) Ietsw., O. vulgare subsp. gracile (K.Koch) Ietsw., O.vulgare subsp. hirtum (Link) Ietsw., O. vulgare subsp. virens (Hoffm. et Link) Ietsw., O. vulgare subsp. viridulum (Martrin-Donos) Nyman (http:// www.theplantlist.org/). As opposed to O. vulgare, the biocidal effects of $O$. vulgare subsp. hirtum (Link) A. Terracc., (Greek oregano) distributed in Southeast Europe and Turkey, are poorly studied. Carvacrol type essential oils from this subspecies influence the germination and radicle elongation of Sinapis arvensis L., Phalaris canariensis L., Lepidium sativum L., and Raphanus sativus L. They also show antifungal activity against the phytopathogens Monilinia laxa, M. fructigena, and $M$. fructicola (Mancini et al., 2014). Antibacterial and antifungal activities of the essential oil of Origanum vulgare subsp. hirtum have also been reported (Adam et al., 1998; Schillaci et al., 2013). La Pergola et al. (2017) have found that carvacrol type commercial oregano oil has more potent repellent activity against Sitophilus oryzae (rice weevil) and Tribolium confusum (confused flour beetle) than the tymol type oil from $O$. vulgare subsp. hirtum.

Aphids are among the most important pests and virus vectors on crops. Myzus persicae Sulz. is a polyphagus that infests plant species from more than 40 families. It is a vector of more than 100 plant viruses, and it has a cosmopolitan distribution. The species is one of the main pests on potato (Blackman and Eastop, 2000; PetrovićObradović et al., 2011). On the other hand, potato is essential crop in Europe and the control of some of its pests with bio-based products, in accordance with the Council Directive 2002/56/EC; Commission Implementing Directive 2014/21/EU for healthy, no diseases, potato seeds. In our preliminary study on herbicide potential of plant extracts and essential oils, Origanum vulgare subsp. hirtum was selected as perspective for more detailed study (YankovaTsvetkova et al., 2020). In the present work the biocidal potential of an essential oil (EO) from O. vulgare subsp. hirtum was evaluated by several experimenthal approaches:

i) assessment of the inhibitory activity of the EO on the germination of the seeds of the target species (Lolium perenne., Trifolium repens and T. pratense) in Petri dishes and soil;

ii) evaluation of phytotoxic effect of the $\mathrm{EO}$ on target weeds in the post-emergence stage and on mature potato plants;

iii) determination of insecticidal effect of the EO on Myzus persicae.

\section{MATERIALS AND METHODS}

\section{Plant Material}

Aerial parts of $O$. vulgare subsp. hirtum were collected during the flowering stage from one of its natural habitats at the Struma valley, Bulgaria. The plant material was air-dried at room temperature in the shade. Seeds of Lolium perenne, Trifolium repens and Trifolium pratense were purchased from Florian Company, Bulgaria (http://www.florianbg. com). Potato cultivar Soraya was purchased from the Potato Experimental Station, Samokov, Bulgaria.

\section{Isolation of the Essential Oil}

The essential oil was extracted on a Clevenger apparatus by water distillation from $50 \mathrm{~g}$ dry plant material in a flask with $500 \mathrm{ml}$ water for $2 \mathrm{~h}$. The extraction was repeated several times to obtain the necessary amount of essential oil for the experiments.

\section{GC/MS Analysis of the Essential Oil}

Oil sample analyses were performed on a Thermo GC equipped with a Focus DSQ II mass detector coupled with a HP-5MS capillary column (30 $\mathrm{m} \times 0.25 \mathrm{~mm}$ i.d., $0.25 \mu \mathrm{m}$ film thicknesses). Chromatographic conditions were as follows: helium as carrier gas at a flow rate of $1 \mathrm{~mL} / \mathrm{min}$; injection volume was $1 \mu \mathrm{l}$, and the split ratio was 1:50. Column temperature was $60^{\circ} \mathrm{C}$ for $10 \mathrm{~min}$, and programmed at the rate of $3^{\circ} \mathrm{C} / \mathrm{min}$ to $200^{\circ} \mathrm{C}$, and finally, held isothermally for $10 \mathrm{~min}$. The injection port was set at $220^{\circ} \mathrm{C}$. Significant quadrupole MS operating parameters: interface temperature $240^{\circ} \mathrm{C}$; electron impact ionization 
at $70 \mathrm{eV}$ with scan mass range of 40 to $400 \mathrm{~m} / \mathrm{z}$ at a sampling rate of $1.0 \mathrm{scan} / \mathrm{s}$ (Traykova et al., 2019). The components were identified by comparing their mass spectra and retentions indexes (RI) with the retention indexes of authentic standards, mass spectra from the National Institute of Standards and Technology (NIST) and literature data (Adams, 2007). The amounts of the identified compounds are relatively expressed as a percentage of the area of all the chromatogram peaks.

\section{Phytotoxic and Insecticidal Activity of the Essential Oil}

\section{Inhibition on Seed Germination in Petri Dishes}

Aqueous solutions of the essential oil, at concentration $0.5,0.75,1,1.5,2$ and $3 \mu \mathrm{L} / \mathrm{mL}$, were prepared using $0.1 \%$ of Tween 40 (Sigma) as an emulsifier. A hundred seeds of Lolium perenne, Trifolium repens and Trifolium pratense were placed in Petri dishes on filter papers moistened with the tested solutions and incubated at room temperature for 7 days. The rate of germination inhibition was calculated by using formula after Atak et al. (2016).

\section{Inhibition on Seed Germination in Soil}

Ten seeds from the tested species Lolium perenne, Trifolium repens and Trifolium pratense, were placed in pots ( $8 \mathrm{~cm}$ in diameter) filled $2 / 3$ with soil and $1 / 3$ with soil and superabsorbent Terawet ${ }^{(\mathrm{R})}$, USA (https:// www.agriculture-xprt.com/companies/terawetgreen-technologies-inc-tgt-90016/) in a ratio of $1: 1$. In advance the superabsorbent was pre-moistened with distilled water for the controls and essential oil solutions at concentrations of 3, 5 and $10 \mu \mathrm{L} / \mathrm{mL}$ of the essential oil. The absorbance ratio of the solution was $5 \mathrm{~g}$ dry crystals per liter of liquid. The pots were stored at room temperature for 30 days and periodically moistened with distilled water from the bottom of the pots. The rate of germination inhibition was calculated by using a formula after Atak et al. (2016).

\section{Phytotoxicity Test}

The phytotoxicity test was performed on seedlings of target plants grown in pots (15 plants per pot, $8 \mathrm{~cm}$ in diameter) and potato plants, cultivar Soraya (one plant per pot, $15 \mathrm{~cm}$ in diameter). The pots were placed in a growth chamber with temperature $23^{\circ} \mathrm{C}$ and 30\% humidity. Potato at vegetative stage and seedlings at cotyledone stage were sprayed with aqueous solutions of $5 \mu \mathrm{L} / \mathrm{mL}$ and $10 \mu \mathrm{L} / \mathrm{mL}$ of the essential oil prepared with 0.1\% Tween 40 (Sigma) as an emulsifier. The spraying rate was $50 \mathrm{~mL} / \mathrm{m}^{2}$ for the weeds and $100 \mathrm{~mL} / \mathrm{m}^{2}$ for the potato plants. Seven days after spraying, the treated plants were checked for visible chlorotic or necrotic areas and mortality. The test was repeated three times for each species. The results are reported as the lethality percentage (LP) using the following formula:
$L P=[(N-n) / N] \times 100$,

where:

$N$...the number of healthy individuals before treatment;

$n . .$. the number of healthy individuals after treatment.

\section{Leaf Dip Bioassay}

„The dip leaf test method“ (FAO) (Anonymous, 1979) with some modifications was applied to evaluate the bioactivity of $O$. vulgare subsp. hirtum essential oil on Myzus persicae on potato plant leaves. Myzus persicae was initially collected from infested plants in the greenhouse of the Institute of Ornamental and Medicinal Plants - Sofia, Bulgarian Agricultural Academy. Some aphid specimens were used for precise identification, which was conducted using permanent microscope slides, after the traditional method of Hille Ris Lambers (1950). The aphid' identification was performed following Blackman and Eastop (2000) identification kay. The aphids were reared in cages in laboratory conditions in a Growth Chamber GC 400 in optimal for their development conditions $-16 / 8 \mathrm{~h}$ light/dark, temperature $23^{\circ} \mathrm{C} \pm 2{ }^{\circ} \mathrm{C}$ and $70 \% \pm 5 \%$ relative humidity. $M$. persicae was reared for more than 30 generations without any pesticide application until we got a standard population to conduct the studies of biocidal effect.

Potatoes were grown as hydroponic in perlite substrate and KNOP medium in a laboratory at the same conditions as the aphids in the growth chamber.

The potato leaves were cut off from the plant and treated through direct dipping into essential oil solutions for $10 \mathrm{sec}$. The solutions were prepared by dissolving in $\mathrm{dH}_{2} \mathrm{O}$ essential oil at eight concentrations $0.1,0.5,1,1.5,2,3,4$ and $5 \mu \mathrm{L} / \mathrm{mL}$. After that leaves were placed on a filter paper for about $30 \mathrm{~min}$ (till solution's evaporation) and in consequence they were placed in Petri dishes with their abaxial surface facing skywards. Thirty adult apterous females were transferred using paint brush in a fine sifter and were dipped into the tested substances for $5 \mathrm{sec}$ after that they were placed onto previously treated leaves in Petri dishes. The tests were conducted in a controlled regime as for the aphids in the growth chamber. The mortality assessment was made under stereo microscope Zeiss 24 hours after the treatment. Aphids' mortality was calculated using Abbott's formula (Abbott, 1925).

$$
\text { Corrected mortality }(\%)=(1-Y / X) \times 100 \text {, }
$$

where:

$X . .$. the number/percent living aphids in control;

$Y$....the number/percent living aphids after the treatment.

The obtained results were compared with a positive control Nurelle $D^{\circledR}$ - a commercial insecticide at a concentration of $0.05 \%$ (as it is recommended for other aphid species), and negative control $-\mathrm{dH}_{2} \mathrm{O}$. 


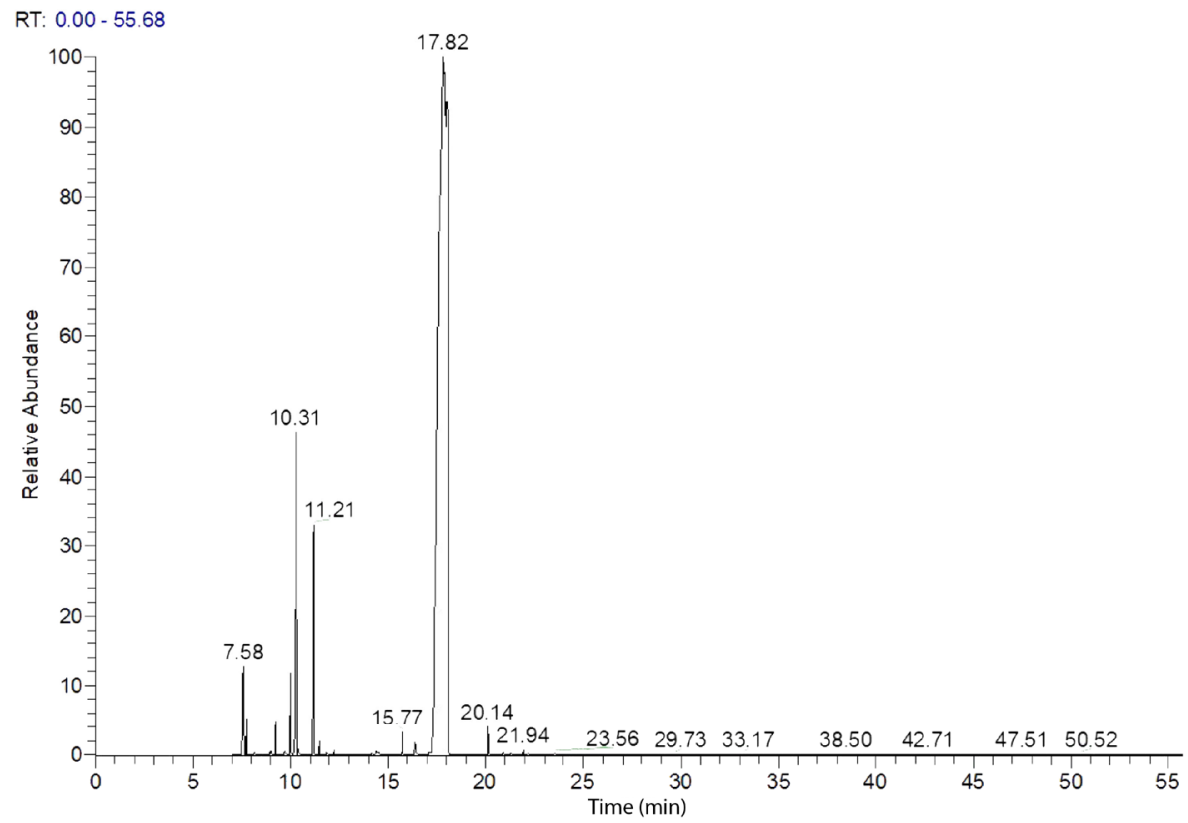

1: GC/MS chromatogram of O. vulgare subsp. hirtum essential oil

\section{Statistical Analysis}

All assays were performed in three independent analyses. The results are presented as mean with standard division (SD). Statistical analyzes were calculated using Microsofte Excel. The $\mathrm{IC}_{50}$ values were calculated by Software Prizm 3.00.

\section{RESULTS AND DISCUSSION}

In the present study the biocidal potential of the essential oil from $O$. vulgare subsp. hirtum on target species: Lolium perenne, Trifolium pratense, Trifolium repens and Myzus persicae was evaluated.

\section{Essential Oil Composition}

Chemical profile of the essential oil from O. vulgare subsp. hirtum was determined by GC/MS. The main components were identified as carvacrol (86.4\%), $p$-cymene (5.98\%), $\gamma$-terpinene (4.24\%), and $\beta$-pinene (1.58\%). The other components are presented in quantities of less than 1\%. The GC/MS chromatogram of essential oil is presented in Fig. 1.
A few chemotypes within the species have been reported in the literature, the dominant being those containing as a major component the phenolic compounds carvacrol/thymol (Martino et al., 2009; Mancini et al., 2014). The carvacrol-rich essential oil composition, reported in the present study, coincides with the most commonly reported for samples from Greece, Italy, Bulgaria, Turkey, and Hungary (Baser et al., 1994; Veres et al., 2003; Konakchiev et al., 2004; Martino et al., 2009; Mancini et al., 2014).

\section{Bioassay of Phytotoxic Effects of the Essential Oil from $O$. vulgare subsp. hirtum}

\section{Inhibition on Seed Germination in Petri Dishes}

The inhibitory activity of the essential oil on seed germination of L. perenne, T. pretense and T. repens was studied in the concentration range of $0.5-3 \mu \mathrm{L} / \mathrm{mL}$. The results expressed as germination inhibition rate are presented in Tab. I.

Inhibitory activity of essential oil was found to be species-dependent and increases with elevation

I: Germination inhibitory activity of essential oil from O. vulgare subsp. hirtum in vitro

\begin{tabular}{cccc}
\hline $\begin{array}{c}\text { Concentraction } \\
{[\mu \mathrm{L} / \mathrm{mL}]}\end{array}$ & \multicolumn{3}{c}{ Germination inhibition [\%] } \\
\cline { 2 - 4 } 0.5 & Lolium perenne & Trifolium repens & Trifolium pratense \\
\hline 0.75 & $84 \pm 7.5$ & $16.3 \pm 4.7$ & $24 \pm 5.3$ \\
1 & $96 \pm 0.5$ & $73 \pm 3.1$ & $32.7 \pm 2.1$ \\
1.5 & $100 \pm 0$ & $96 \pm 0.5$ & $59 \pm 5.7$ \\
2 & $100 \pm 0$ & $97 \pm 0.3$ & $93.7 \pm 5.4$ \\
3 & $100 \pm 0$ & $100 \pm 0$ & $100 \pm 0$ \\
\hline
\end{tabular}


concentration. Lolium perenne seeds were found to be the most sensitive to the treatment with essential oil whereas T. pratense was the least sensitive. Total inhibition of seed germination of the tested species was achieved with a solution at a concentration of $2 \mu \mathrm{L} / \mathrm{mL}$ of essential oil. Such an inhibitory concentration is comparable with those reported for essential oils from plants considered as strong bio-herbicides as Satureja hortensis, S. montana, Mentha piperita, boldo and lemon grass (Blázquez and Carbó, 2015; Amri et al., 2013b; Ibáñez and Blázquez, 2017).

Total inhibition in concentration range $4-5 \mu \mathrm{L} / \mathrm{mL}$ of essential oil has been considered as potent (Amri et al., 2017). Our results are also similar to those of Mancini et al., (2014) and Ibáñez and Blázquez (2017) who reported inhibitory activity of $O$. vulgare subsp. hirtum essential oil on seed germination of other weed species.

\section{Inhibition on Seed Germination in Soil}

Most of the phytotoxicity experiments with essential oils are performed in vitro in Petri dishes while data from in vivo experiments are limited. The inhibitory effect of Origanum essential oil on seed germination of target species was examined with solutions at three concentrations, 3, 5 and $10 \mu \mathrm{L} / \mathrm{mL}$ in soil. The use of the superabsorbent Terawet $^{\mathrm{R}}$ in the experiment prevented the rapid evaporation of the essential oil that prolonged the effectiveness of treatment. The results expressed as germination inhibition rate are presented in Tab. II and Fig. 2. Similarly to the results from the in vitro assay, the inhibitory effect of the essential oil on seed germination was found to be speciesdependent and increases in a concentrationdependent manner.

However, the effective concentrations for soil treatment are considerably higher as compared to the in vitro trials. In contrast to in vitro germination assay, Lolium perrene is less sensitive than the Trifolium species which germination was inhibited

II: Germination inhibitory activity of essential oil from O. vulgare subsp. hirtum in soil

\begin{tabular}{cccc}
\hline \multirow{2}{*}{$\begin{array}{c}\text { Concentraction } \\
{[\mu \mathrm{L} / \mathrm{mL}]}\end{array}$} & \multicolumn{3}{c}{ Germination inhibition [\%] } \\
\cline { 2 - 4 } 3 & Lolium perenne & Trifolium repens & Trifolium pratense \\
\hline 5 & $47 \pm 7.1$ & $92 \pm 0.5$ & $89 \pm 3.3$ \\
10 & $64 \pm 9.8$ & $100 \pm 0$ & $97 \pm 5.7$ \\
\hline
\end{tabular}

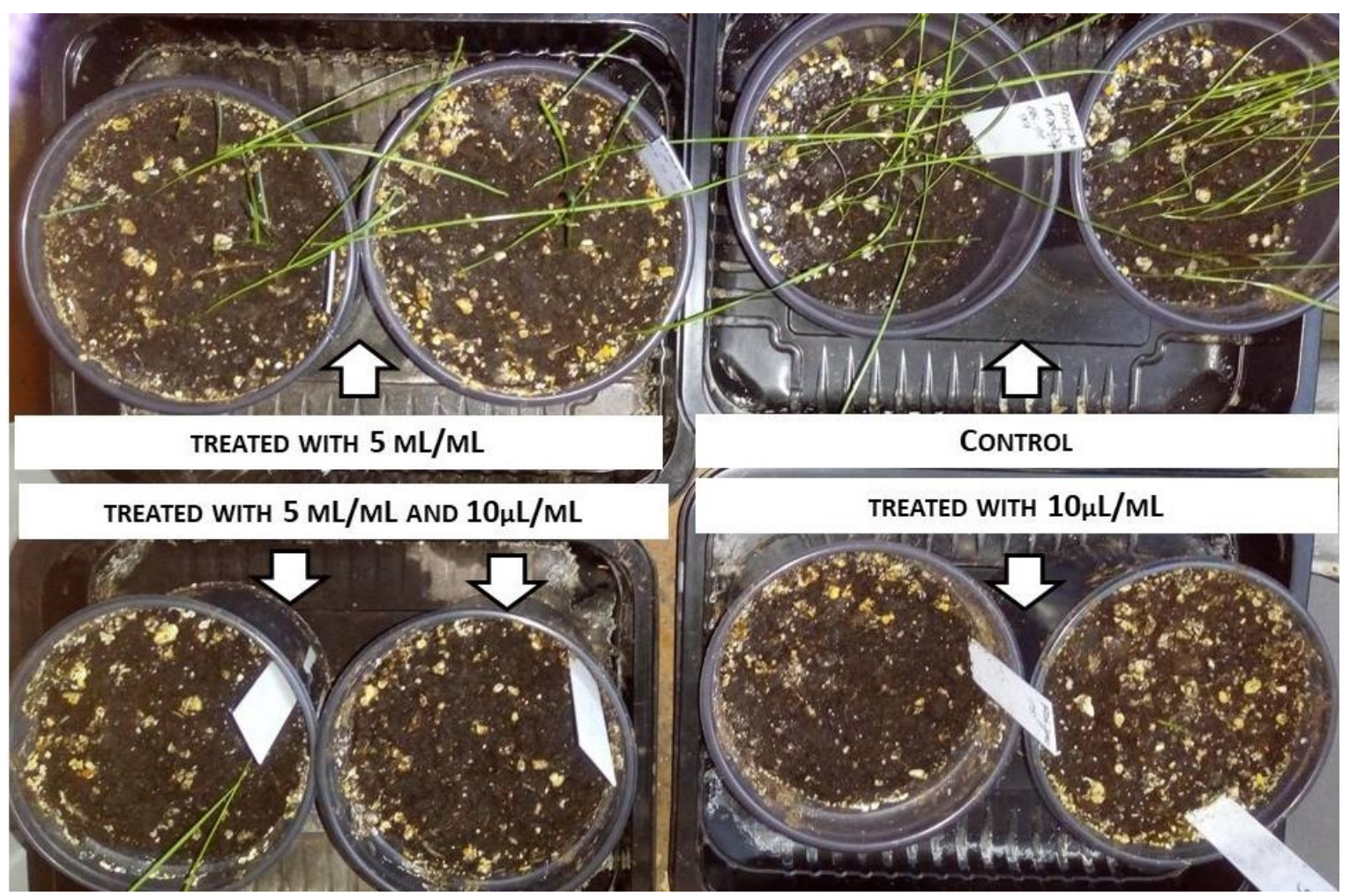

2: Effect of application of O. vulgare subsp. hirtum essential oil at a concentration of 5 and $10 \mu \mathrm{L} / \mathrm{mL}$ in soil with L. perrene seeds 
$47 \%$ and $67 \%$ with solutions at a concentration of 3 and $5 \mu \mathrm{L} / \mathrm{mL}$. Treatment with solutions at concentration of $10 \mu \mathrm{L} / \mathrm{mL}$ of essential oil resulted in $97 \%$ inhibition of germination of $L$. perenne seeds and complete germination inhibition in the Trifolium species. The latter species were inhibited over $80 \%$ even with a solution of essential oil with a concentration of $3 \mu \mathrm{L} / \mathrm{mL}$. Frabboni et al., (2019) have been reported that soil treatment with 50\% diluted and undiluted oil $O$. vulgare essential oil inhibited weed seed germination. Application of Origanum green manure in corn and cotton fields suppressed the germination of weeds significantly and increased the yields greatly compared to the controls (Vasilakoglou et al., 2011). The high volatility of essential oils is a major problem when applied in field conditions. Recent studies have been published that this problem is solved through the application of essential oils by microencapsulation and nanoemulsion (Hazrati et al., 2017). In the present study, a solution of essential oil is included in a superaborbent, which ensures the gradual release of the oil into the soil, which prolongs its action.

\section{Phytotoxicity Assay}

The phytotoxicity effect of Origanum essential oil was evaluated on seedlings of target species and potato plants by spraying on solutions with concentration 5 and $10 \mu \mathrm{L} / \mathrm{mL}$. Seven days after the seedling treatment with $5 \mu \mathrm{L} / \mathrm{mL}$ essential oil solution, the lethality rates were $13 \%$ for the T. pratense individuals and 39\% for the T. repens individuals. The $L$. perenne individuals were very poorly affected, which is manifested by yellowing some individuals' top part. A solution with concentration at $10 \mu \mathrm{L} / \mathrm{mL}$ resulted in lethality rates of $100 \%, 97 \%$ and $66 \%$ for individuals of T. repens, T. pratense and L. perenne, respectively. The results are presented in Tab. III and Fig. 3.

The received results determined the phytotoxicity of the essential oil from $O$. vulgare ssp. hirtum is much stronger than essential oils from other plants such as Artemisia annua and Xanthium strumarium, which have shown activity at a concentration of $1000 \mu \mathrm{L} / \mathrm{mL}$ (Benvemti et al., 2017). Hazrati et al. (2017) reported complete lethality on Amaranthus retroflexus and Chenopodium album 10 days post-treatments with

III: Lethality of weed individuals seven days after treatment with O. vulgare subsp. hirtum essential oil

\begin{tabular}{lcc}
\hline \multicolumn{1}{c}{ Weed species } & Concentration $[\mu \mathrm{L} / \mathrm{mL}]$ & Lethality of individuals [\%] \\
\hline Loliun perenne & 5 & $0 \pm 0$ \\
\hline \multirow{2}{*}{ Trifollium pratense } & 10 & $66 \pm 19$ \\
\hline \multirow{2}{*}{ Trifollium repens } & 5 & $92 \pm 8$ \\
& 10 & $97 \pm 5$ \\
\hline
\end{tabular}
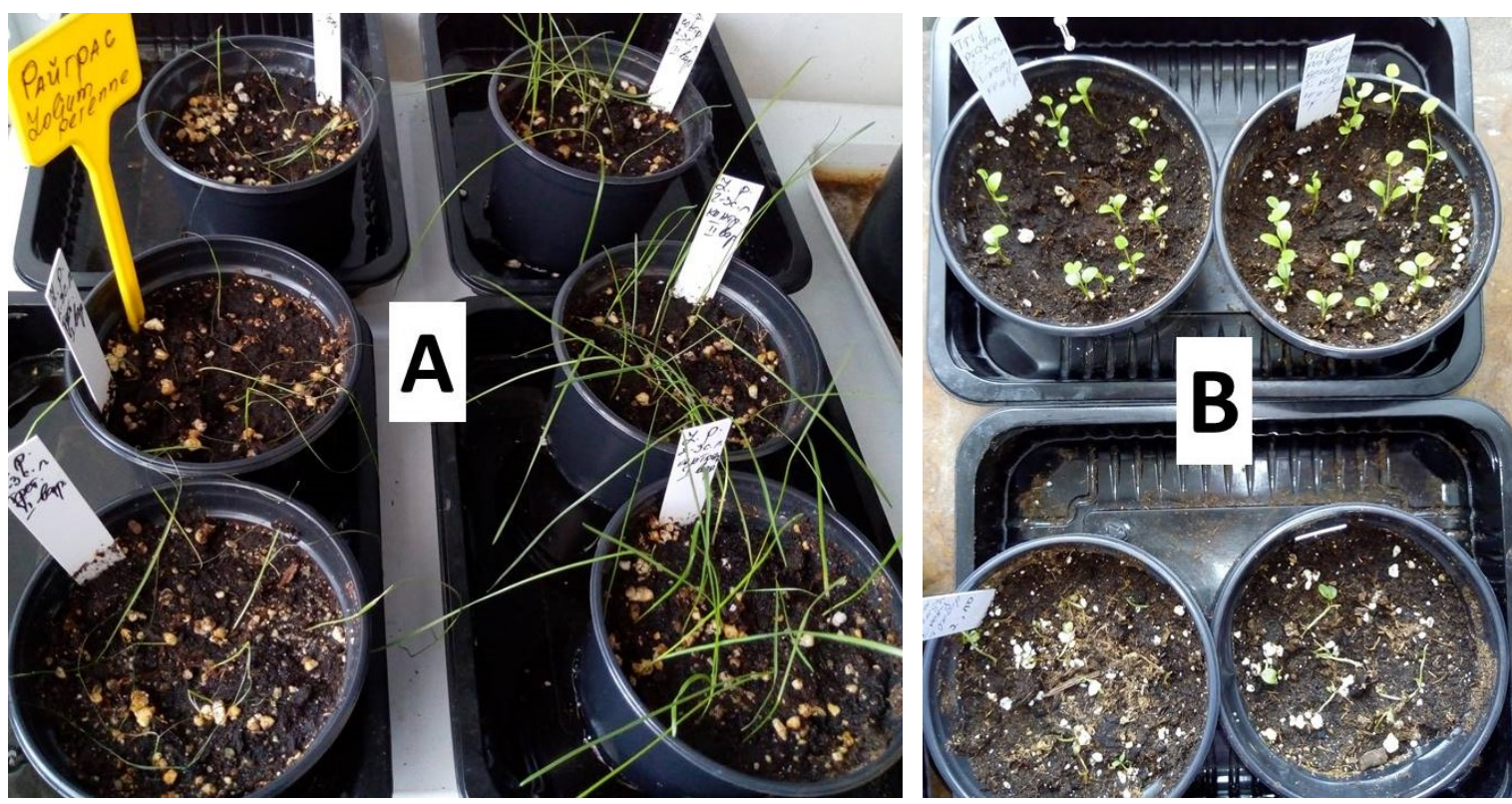

3: Effect of application of O. vulgare subsp. hirtum essential oil at a concentration of $10 \mu \mathrm{L} / \mathrm{mL}$ on the survival of L. perrene (A) and T. pratense $(B)$ 
nanoemulsion of essential oil of Satureja hortensis at a concentration $4 \mu \mathrm{L} / \mathrm{mL}$.

Complete weed control has been achieved with 5 to $10 \%$ solutions of cinnamon and clove essential oils (Tworkoski, 2002). Post-emergence application of Artemisia scoparia oil (2\%, 4\%, and $6 \%, \mathrm{v} / \mathrm{v})$ on 6-week-old weed plants has been reported to cause visible injury ranging from chlorosis to complete wilting of target plants (Cassia occidentalis, Parthenium hysterophorus, Echinochloa crus-galli and Ageratum conyzoides) (Kaur et al., 2010). On the other hand, our results are in accordance with Dayan et al. (2009) and Amri et al. (2012) who have established that dicot weeds are more sensitive than monocot ones.

The treatment of potato plants with the Origanum essential oil solutions resulted in slight phytotoxic effects. Small spots were observed on the surface of single leaves. Similarly, Synowiec et al. (2017) have observed that the crops are more resistant than weeds to the toxicity effects of essential oils. Moreover, the authors suggest that seed size is related to its resistance to essential oils. In their experience, this has been observed with Zea mays seeds. The results of the present study with potato tubers confirm these conclusions.

In summary, we suppose that the potent phytotoxicity of the $O$. vulgare ssp. hirtum essential oil is due to its major (over 80\%) component, carvacrol. Several articles point to carvacrol as a potent inhibitor of seed germination (De Almeida et al., 2010; Synowiec et al., 2016; Ulukanli et al., 2018; Bendre et al., 2018). Araniti et al., (2018) show in experiments with Arabidopsis thaliana seedlings that oregano essential oil disrupts the absorption of inorganic nitrogen in amino acids, which destroy the metabolism of glutamine and leads to an excess of ammonia in the leaves, that causes destructive chain processes (oxidative stress, disorders of photosynthesis and etc.). All these processes lead to destruction of the plant.

\section{Bioassay of Insecticidal Activity of the Essential Oil from $O$. vulgare subsp. hirtum}

The results of the insecticidal test showed that the essential oil had completely toxic effects on Myzus persicae at a concentration $3 \mu \mathrm{L} / \mathrm{mL}$. Dosedependent increase of the biocidal activity was obtained after the treatment with the essential oil on M. persicae. Immediately after the $5 \mathrm{sec}$ treatment with concentrations of $3 \mu \mathrm{L} / \mathrm{mL}$ or higher (obtained from dry and fresh leaves) a knock out effect (i.e. $100 \%$ aphid mortality) was observed. At the same concentrations, potato leaves revealed a slight phytotoxic effect after 10 sec. direct dip application. Lack of phytotoxic effect on leaves and insignificant mortality of aphids were reported at concentrations
IV: Aphid mortality after treatment with O. vulgare subsp. hirtum essential oil

\begin{tabular}{cc}
\hline $\begin{array}{c}\text { Concentration } \\
{[\mu \mathrm{L} / \mathrm{mL}]}\end{array}$ & $\begin{array}{c}\text { Aphid mortality after treatment } \\
{[\%]}\end{array}$ \\
\hline 0.1 & $0 \pm 0.8$ \\
0.5 & $5 \pm 1.6$ \\
1 & $10 \pm 1.4$ \\
1.5 & $15 \pm 0.8$ \\
2 & $30 \pm 1.4$ \\
\hline 3 & $100 \pm 0.8$ \\
4 & $100 \pm 0$ \\
5 & $100 \pm 0$ \\
\hline
\end{tabular}

lower than $2 \mu \mathrm{L} / \mathrm{mL}$ (Tab. IV). The $\mathrm{IC}_{50}$ value - extract concentration providing 50\% aphid mortality was calculated as $2.2 \mu \mathrm{L} / \mathrm{mL}$. As a comparison, the positive control Nurelle $\mathrm{D}^{\circledR}$ resulted in $100 \%$ mortality in aphids and no phytotoxic effect was observed on the leaves. Unlike the above-reported phytotoxicity on the treated cut off potato leaves, the laboratory tests on whole potato plants, sprayed with $5 \mu \mathrm{L} / \mathrm{mL}$ essential oil, resulted in a less visible effect. That gives us a suggestion that the whole plants are more resistant to the essential oil application than the cut off leaves directly dipped into the tested essential oil solutions.

Our results confirm an earlier conducted laboratory experiments with $O$. vulgare essential oil, showing a strong insecticidal activity against the cotton aphid - Aphis gossypii Glover, which is very close to the activity of another standard insecticide Karate Zeon ${ }^{\circledR}$ (Atanasova et al., 2018). According to Dancewicz et al. (2012) it was found that the essential oil of $O$. vulgare also posses a strong and long-lasting deterrent effect on the pea aphid Acyrthosiphon pisum Harris, but it has a weak and transitory deterrent effect on $M$. persicae. It is also revealed that the oligophagous $A$. pisum is more sensitive to this essential oil comparing to M. persicae. As a suggestion further experiments might prove that the essential oil of $O$. vulgare ssp. hirtum could also be used as an insect repellent against certain pest species. On the other hand, the polyphagous insects have the ability to avoid/ reduce the toxic effect of many xenobiotics and pesticides by expressing a wide range of enzymes (Li et al., 2000). We suppose that the results obtained by us might show even better insecticidal activity of $O$. vulgare ssp. hirtum essential oil on some other pests, especially oligophagous and monophagous aphids. This assumption is confirmed by Digilio et al., (2008) for O. vulgare essential oil, proving that A. pisum is more susceptible to the treatment than M. persicae. 


\section{CONCLUSION}

The results have shown that the essential oil of $O$. vulgare subsp. hirtum exhibits a potent inhibitory activity on seed germination of L. perenne, T. pretense and T. repens at concentration of $2 \mu \mathrm{L} / \mathrm{mL}$, it destroys the target weeds at a concentration of $10 \mu \mathrm{L} / \mathrm{mL}$, and posssess inhibitory activity against the development of aphids on potatoes at a concentration of $3 \mu \mathrm{L} / \mathrm{mL}$. By the inclusion of the oil in the superabsorbent Terawet ${ }^{\mathbb{R}}$ was overcome its rapid evaporation upon application to the soil. Complete inhibition of seed germination in soil was achieved at a concentration of $5 \mu \mathrm{L} / \mathrm{mL}$ of essential oil for studied dicot and at $10 \mu \mathrm{L} / \mathrm{mL}$ for the monocot species. Further field experiments are necessary to prove the effectiveness of Origanum vulgare subsp. hirtum essential oil for control of pests in field experiments.

\section{Acknowledgements}

This research was supported by the Bulgarian National Science Fund, Bulgarian Ministry of Education and Science (Grant DN 16/2, 11.12.2017).

\section{REFERENCES}

BLANCO, C., GIRALDEZ, F. J., PRIETO, N., MORAN, L., ANDRES, S., BENAVIDES, J., TEJIDO, M. L. and BODAS, R. 2014. Effects of dietary inclusion of sunflower soap stocks on nutrient digestibility, growth performance, and ruminal and blood metabolites of light fattening lambs. Journal of Animal Science, 92(9): 4086-4094.

ABBOTT, W. S. 1925. A method of computing the effectiveness of an insecticide. Journal of Economic Entomology, 18(2): 265-267.

ADAM, K., SIVROPOULOU, A., KOKKINI, S., LANARAS, T. and ARSENAKIS, M. 1998. Antifungal activities of Origanum vulgare subsp. hirtum, Mentha spicata, Lavandula angustifolia, and Salvia fruticosa essential oils against human pathogenic fungi. Journal of Agricultural and Food Chemistry, 46(5): 1739-1745.

ADAMS, R. 2007. Identification of essential oil components by gas chromatography/mass spectrometry. $4^{\text {th }}$ Edition. Allured Pub Corp.

AMRI, I., HAMROUNI, L., HANANA, M. and JAMOUSSI, B. 2012. Herbicidal potential of essential oils from three Mediterranean trees on different weeds. Current Bioactive Compounds, 8(1): 3-12.

AMRI, I., HAMROUNI, L., HANANA, M. and JAMOUSSI, B. 2013a. Reviews on phytotoxic effects of essential oils and their individual components: news approach for weeds management. International Journal of Applied Biology and Pharmaceutical Technology, 4: 96-114.

AMRI, I., HAMROUNI, L., HANANA, M., GARGOURI, S., FEZZANI, T. and JAMOUSSI, B. 2013b. Chemical composition, physico-chemical properties, antifungal and herbicidal activities of Pinus halepensis Miller essential oils. Biological Agriculture and Horticulture, 29(2): 91-106.

AMRI, I., HANANA, M., JAMOUSSI, B. and JAMOUSSI, B. 2017. Essential oils of Pinus nigra J. F. Arnold subsp. laricio Maire: Chemical composition and study of their herbicidal potential. Arabian Journal of Chemistry, 10(S2): S3877-S3882.

FAO. 1979. Recommended methods for the detection and measurement of resistance of agricultural pests to pesticides, Method for adult aphids. FAO Plant Protection Bulletin, 27: 29-32.

ARANITI, F., LANDI, M., LUPINI, A., SUNSERI, F., GUIDI, L. and ABENAVOLI, M. 2018. Origanum vulgare essential oils inhibit glutamate and aspartate metabolism altering the photorespiratory pathway in Arabidopsis thaliana seedlings. Journal of Plant Physiology, 231: 297-309.

ATAKM, M., MAVI, K. and UREMIS, I. 2016. Bio-herbicidal effects of oregano and rosemary essential oils on germination and seedling growth of bread wheat cultivars and weeds. Romanian Biotechnological Letters, 21(1): 11149-11159.

ATANASOVA, D., GANCHEV, D. and NENOV, N. 2018. Efficacy of some plant essential oils against cotton aphid, Aphis gossypii Glover (Hemiptera: Aphididae) under laboratory conditions. Journal of Agricultural Science, 1: 10-16.

BASER, K. H. C., ÖZEK, T., KÜRKCÜOGLU, M. and TÜMEN, G. 1994. The essential oil of Origanum vulgare subsp. hirtum of Turkish origin. Journal of Essential Oil Research, 6(1): 31-36.

BENDRE, R. S., BAGUL, S. D. and RAJPUT, J. 2018. Carvacrol: an excellent natural pest control agent. Natural Products Chemistry and Research, 6(6): 1000349.

BENVENUTI, S., CIONI P. L., FLAMINI, G. and PARDOSSI, A. 2017. Weeds for weed control: Asteraceae essential oils as natural herbicides. Weed Research, 57(5): 342-353.

BERKOV, S., MUTAFOVA, B. and CHRISTEN, P. 2014. Molecular biodiversity and recent analytical developments: a marriage of convenience. Biotechnology Advances, 32(6): 1102-1110. 
BLACKMAN, R. L. and EASTOP, V. F. 2000. Aphids on The World's Crops. An identification and Information Guide. $2^{\text {nd }}$ Edition. London: The Natural History Museum.

BLÁZQUEZ, M. A. and CARBÓ, E. 2015. Control of Portulaca oleracea by boldo and lemon essential oils in different soils. Industrial Crops and Products, 76: 515-521.

DANCEWICZ, K., KARDAN, B., SZUMNY, A. and GABRYS, B. 2012. Aphid behaviour-modifying activity of essential oils from Lamiaceae and Apiaceae. Aphids and Other Hemipterous Insects, 18: 93-100.

DAYAN, F. E., CANTRELL, C. L. and DUKE, S. O. 2009. Natural products in crop protection. Bioorganic and Medicinal Chemistry, 17(12): 4022-4034.

DHIFI, W., BELLINI, S., JAZI, N., BAHLOUL, S. and MNIF, W.2016. Essential oils' chemical characterization and investigation of some biological activities: a critical review. Medicines, 3(4): 25.

DE ALMEIDA, L. F. R., FREI, F. MANCINI, E., DE MARTINO, L. and DE FEO, V. 2010. Phytotoxic activities of Mediterranean essential oils. Molecules, 15(6): 4309-4323.

DE MARTINO, L., DE FEO V., FORMISANO, C., MIGNOLA, E. and SENATORE, F. 2009. Chemical composition and antimicrobial activity of the essential oils from three chemotypes of Origanum vulgare L. ssp. hirtum (Link) Ietswaart growing wild in Campania (Southern Italy). Molecules, 14(8): 2735-2746.

DIGILIO, M. C., MANCINI E., VOTO, E. and DE FEO, V. 2008. Insecticide activity of Mediterranean essential oils. J Plant Interact., 3(1): 17-23.

DRAGOEVA, A. P., KOLEVA, V., NANOVA, Z. D., KASCHIEVA, M. Z. and YOTOVA, I. R. 2014. Allelopathic and cytotoxic activity of Origanum vulgare ssp. vulgare growing wild in Bulgaria. Chemistry: Bulgarian Journal of Science Education, 23(6): 914-924.

DUBEY, N., SRIVASTAVA, B. and KUMAR, A. 2008. Current status of plant products as botanical pesticides in storage pest management. Journal of Biopesticides, 1: 182-186.

GARCÍA-BELTRÁN, J. M. and ESTEBAN, M. A. 2016. Properties and applications of plants of Origanum sp. genus. SM Journal of Biology, 2(1): 1006.

GONZALEZ-COLOMA, A., REINA, M., DIAZ, C., FRAGA M. and SANTANA-MERIDAS, O. 2013. Natural product-based biopesticides for insect control. In: Reference Module in Chemistry, Molecular Sciences and Chemical Engineering. Elsevier.

GRONDONA, E., GATTI, G., LÓPEZ, A. G., SÁNCHEZ, L. R., RIVERO, V., PESSAH, O., ZUNINO, M. P. and PONCE, A. A. 2014. Bio-efficacy of the essential oil of Oregano (Origanum vulgare Lamiaceae. Ssp. hirtum). Plant Foods for Human Nutrition, 69(4): 351-357.

GRULOVÁ, D., CAPUTO L., ELSHAFIE, H. S., BARANOVÁ, B., DE MARTINO, L., SEDLÁK, V., GOGALOVÁ, Z., PORÁCOVÁ, J., CAMELE, I. and DE FEO, V. 2020. Thymol chemotype Origanum vulgare L. essential oil as a potential selective bio-based herbicide on monocot plant species. Molecules, 25(3): 595.

FRABBONI, L., TARANTINO, A., PETRUZZI, F. and DISCIGLIO, G. 2019. Bio-herbicidal effects of oregano and rosemary essential oils on chamomile (Matricaria chamomilla L.) crop in organic farming system. Agronomy, 9(9): 475.

HAZRATI, H., SAHARKHIZ, M. J., NIAKOUSARI, M. and MOEIN, M. 2017. Natural herbicide activity of Satureja hortensis L. essential oil nanoemulsion on the seed germination and morphophysiological features of two important weed species. Ecotoxicology and Environmental Safety, 142: 423-430.

IBÁÑEZ, M. D. and BlÁZQUEZ, M. A. 2018. Phytotoxicity of essential oils on selected weeds: potential hazard on food crops. Plants, 7(4): 79.

IBÁÑEZ, M. D. and BlÁZQUEZ, M. A. 2017. Herbicidal value of essential oils from oregano-like flavour species. Food and Agricultural Immunology, 28(6): 1168-1180.

KAUR, S., SINGH, H. P., MITTAL, S., BATISH, D. R. and KOHLI, R. K. 2010. Phytotoxic effects of volatile oil from Artemisia scoparia against weeds and its possible use as a bioherbicide. Industrial Crops and Products, 32(1): 54-61.

KONAKCHIEV, A., GENOVA, E. and COULADIS, M. 2004. Chemical composition of the essential oil of Origanum vulgare ssp. hirtum (Link) Ietswaart in Bulgaria. Comptes rendus de l'Academie bulgare des Sciences, 57: 49-52.

LA PERGOLA, A., RESTUCCIA, C., NAPOLI, E., BELLA, S., BRIGHINA, S., RUSSO A. and SUMA, P. 2017. Commercial and wild Sicilian Origanum vulgare essential oils: chemical composition, antimicrobial activity and repellent effects. Journal of Essential Oil Research, 29(6): 451-460.

LI, X., BERENBAUM, M. R. and SCHULER, M. A. 2000. Molecular cloning and expression of CYP6B8: a xanthotoxin inducible cytochrome P450 cDNA from Helicoverpa zea. Insect Biochemistry and Molecular Biology, 30(1): 75-84.

MANN, R. S. and KAUFMAN, E. 2012. Natural product pesticides: Their development, delivery and use against insect vectors. Mini-Reviews in Organic Chemistry, 9(2): 185-202.

MANCINI, E., CAMELE, I., ELSHAFIE, H. S., DE MARTINO, L., PELLEGRINO, C., GRULOVA, D. and DE FEO, V. 2014. Chemical composition and biological activity of the essential oil of Origanum vulgare ssp. 
hirtum from different areas in the southern Apennines (Italy). Chemistry and Biodiversity, 11(4): 639-651.

PETROVIĆ-OBRADOVIĆ, O., LECLANT, F. and TOMANOVIĆ, Ž. 2011. Catalogue of Aphids of Durmitor (Insecta, Hemiptera, Aphididae). Podgorica: Montenegrin Academy of Sciences and Arts.

SARIKURKCU, C., ZENGIN, G., OSKAY, M., UYSAL, S., CEYLAN, R. and AKTUMSEK, A. 2015. Composition, antioxidant, antimicrobial and enzyme inhibition activities of two Origanum vulgare subspecies (subsp. vulgare and subsp. hirtum) essential oils. Industrial Crops and Products, 70: 178-184.

SCHILLACI, D., NAPOLI, E. M. CUSIMANO, M. G., VITALE, M. and RUBERTO, G. 2013. Origanum vulgare subsp. hirtum essential oil prevented biofilm formation and showed antibacterial activity against planktonic and sessile bacterial cells. Journal of Food Protection, 76(10): 1747-1752.

SCOGNAMIGLIO, M., D'ABROSCA, B., ESPOSITO, A., PACIFICO, S., MONACO, P. and FIORENTINO, A. 2013. Plant growth inhibitors: allelopathic role or phytotoxic effects? Focus on Mediterranean biomes. Phytochemistry Reviews, 12(4): 803-830.

SYNOWIEC, A., KALEMBA, D., DROZDEK, E. and BOCIANOWSKI, J. 2017. Phytotoxic potential of essential oils from temperate climate plants against the germination of selected weeds and crops. Journal of Pest Science, 90(1): 407-419.

TRAYKOVA, B., STANILOVA, M., NIKOLOVA, M. and BERKOV, S. 2019. Growth and essential oils of Salvia officinalis plants derived from conventional or aeroponic produced seedlings. Agriculturae Conspectus Scientificus, 84(1): 77-81.

TWORKOSKI, T. 2002. Herbicide effects of essential oils. Weed Science, 50(4): 425-431.

ULUKANLI, Z., CENET, M., HUSEYIN, I. and YILMAZTEKIN, M. 2018. Antimicrobial and herbicidal activities of the essential oil from the Mediterranean Thymus eigii. Journal of Essential Oil Bearing Plants, 21(1): 214-222.

VASILAKOGLOU, I., DHIMA, K., ANASTASSOPOULOS, E., LITHOURGIDIS, A., GOUGOULIAS N. and CHOULIARAS, N. 2011. Oregano green manure for weed suppression in sustainable cotton and corn fields. Weed Biology and Management, 11(1): 38-48.

VERES, K., VARGA, E., DOBOS, A., HAJDÚ, Z. S., MÁTHÉ, I., NÉMETH, E. and SZABÓ, K. 2003. Investigation of the composition and stability of the essential oils of Origanum vulgare ssp. vulgare L. and O. vulgare ssp. hirtum (Link) Ietswaart. Chromatographia, 57(1-2): 95-98.

VOKOU, D., DOUVLI, P., BLIONIS, G. J. and HALLEY, J. M. 2003. Effects of monoterpenoids, acting alone or in pairs, on seed germination and subsequent seedling growth. Journal of Chemical Ecology, 29: 2281-2301.

YANKOVA-TSVETKOVA, E., NIKOLOVA, M., ANEVA, I., STEFANOVA, T. and BERKOV, S. 2020. Germination inhibition bioassay of extracts and essential oils from plant species. Comptes rendus de l'Académie bulgare des Sciences, 73(9): 1254-1259.

Contact information

Milena Nikolova: mtihomirova@gmail.com (corresponding author) 